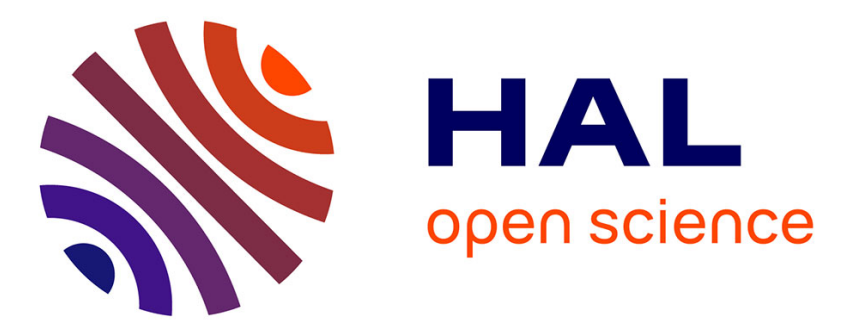

\title{
A Bibliometric Analysis of the Knowledge Exchange Patterns between Major Technology and Innovation Management Journals (1999-2013)
}

\author{
Shikhar Sarin, Christophe Haon, Mustapha Belkhouja
}

\section{To cite this version:}

Shikhar Sarin, Christophe Haon, Mustapha Belkhouja. A Bibliometric Analysis of the Knowledge Exchange Patterns between Major Technology and Innovation Management Journals (1999-2013). Journal of Product Innovation Management, 2018, 35 (1), pp.2-8. 10.1111/jpim.12431 . hal-01705065

\section{HAL Id: hal-01705065 \\ https://hal.univ-smb.fr/hal-01705065}

Submitted on 9 Feb 2018

HAL is a multi-disciplinary open access archive for the deposit and dissemination of scientific research documents, whether they are published or not. The documents may come from teaching and research institutions in France or abroad, or from public or private research centers.
L'archive ouverte pluridisciplinaire HAL, est destinée au dépôt et à la diffusion de documents scientifiques de niveau recherche, publiés ou non, émanant des établissements d'enseignement et de recherche français ou étrangers, des laboratoires publics ou privés. 


\title{
A Bibliometric Analysis of the Knowledge Exchange Patterns between Major Technology and Innovation Management Journals (1999 - 2013)
}

\author{
Shikhar Sarin \\ Professor of Marketing \\ College of Business and Economics \\ Boise State University \\ Boise, ID 83725 \\ Phone: (208) 426-2721 \\ E-mail: ssarin@boisestate.edu
}

\author{
Christophe Haon \\ Professor of Marketing \\ Grenoble Ecole de Management, Univ. Savoie Mont Blanc - IREGE \\ 12 rue Pierre Sémard, 38000 Grenoble, France \\ Phone: +44 476706516 \\ E-mail: christophe.haon@grenoble-em.com
}

Mustapha Belkhouja

Assistant Professor

Grenoble Ecole de Management

12 rue Pierre Sémard, 38000 Grenoble, France

E-mail: mustapha.belkhouja@grenoble-em.com

The authors would like to thank Gloria Barczak for her advice and insightful feedback on earlier versions of this essay. They would also like to acknowledge Vincent Mangematin for providing access to the data. 


\section{A Bibliometric Analysis of the Knowledge Exchange Patterns between Major Technology and Innovation Management Journals (1999 - 2013)}

\section{Introduction}

It is healthy, even vital, for a domain area to conduct periodic and critical self-evaluation of its impact and evolution. Over the years, disciplines like marketing have engaged in several such “state of the discipline” appraisals (e.g., Biggadike 1981; Day 1992; Day and Montgomery 1999; Varadarajan and Jayachandran 1999; Pieters and Baumgartner 2002; Reibstein et al. 2009 etc.).

In a recent evaluation, Clark et al (2014) analyzed aggregate levels of citation flows between the top four journals of major business disciplines to show that Marketing was a net importer of knowledge from other related business disciplines, and largely isolated. Similar analyses have also been conducted on the knowledge structures of a broadly classified innovation area (e.g., Shafiq 2013). However, aggregate level citation data do not provide us with the directionality or evolution of such trends over the years. To our knowledge, we are lacking a longitudinal perspective on the impact and evolution of knowledge exchange patterns in the Technology and Innovation Management (TIM) domain.

The purpose of this essay is to take a dynamic, longitudinal look at the citation flows between the top dedicated TIM journals, and its effect on their impact factors. Specifically, we take a year-by-year look at the following trends:

1) The level of self-citation by major TIM journals

2) The level of cross-citations between the major TIM journals

3) The effect of self-citation and citation of other major TIM journals on the impact factor of each journal. 


\section{Data}

We extracted article-by-article citation data from 336 journals in major business disciplines from the Web of Science, from 1994 to 2013. This bibliometric database contained data on a total of 135,559 articles and 5,998,130 citations. However, some of the journals have a later start date, depending upon when they were incorporated in the database.

Starting with the dedicated TIM journals identified by Linton and Thongpapanl (2004), we focused on the top six (major) TIM journals based on average Impact Factor in order to keep the analyses and presentation manageable. Our final analysis was carried out on the following major dedicated TIM journals: Journal of Product Innovation Management, Research Policy, $R \& D$ Management, IEEE Transactions on Engineering Management, Technovation, and Technological Forecasting and Social Change. A full set of data for these journals in our consideration set were available only from 1999 - 2013. The final analyses for this essay were conducted on 29,776 citations from 4,171 articles published by these top six selected TIM journals.

In order to account for the differences in the number of articles published by each journal per year, and the number of references cited per article among different journals, we adopted the approach recommended by Di Benedetto et al (2018). All citation data were normalized and presented in terms of the percentage of all references cited in that journal, in that year as reported by Scimago Journal \& Country Rank (http://www.scimagojr.com). The journal impact factors (IF) were extracted from Thomson Reuters database.

\section{Findings}

Figure 1 shows the evolution in the 2-year impact factor of journals under consideration from 1999 - 2013. It can be seen that most major dedicated TIM journals saw their 2-year 
impact factor rise significantly starting 2005-2007, to peak 2 to 5 years later, before starting to show some decline. An analysis of self-citation over this period could perhaps provide a tentative explanation of this general trend.

Figure 1: 2-Year Impact Factors of Major Dedicated TIM Journals (1999 - 2013)

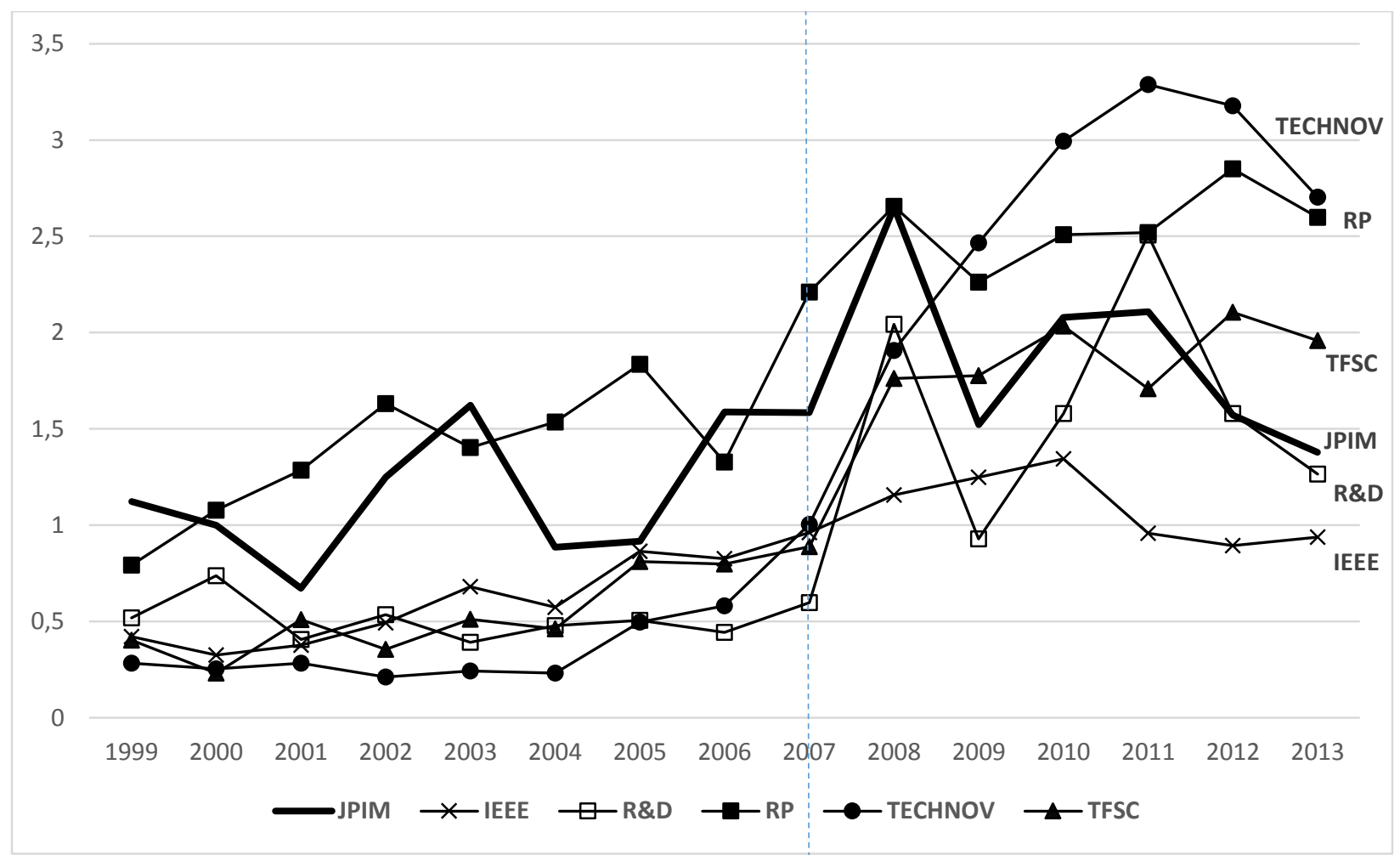

$\underline{\text { Self-Citation Analysis of Major TIM Journals (1999 - 2013) }}$

Figure 2 presents the rates of self-citation among the six major TIM journals over the 19992013 period. Patterns of self-citation by the major TIM journals suggest two distinct periods/phases, before 2006/2008 and after 2006/2008 (the transition year depends on the journals):

- The self-citation rates are rather steady before $2006 / 2008$ for most journals except for JPIM. JPIM started out with the highest self-citation rates prior to 2005 , but the rate decreased overall between 2005-2008, before climbing again. However, since 2008, the 
JPIM self-citation rates have been more aligned with those of the other major TIM journals - though they still on the higher side in the consideration set;

- From 2006/2008 onwards, the self-citation rates increased for all major TIM journals, especially for Research Policy, Technovation, and JPIM (which hovered around 9\% each in 2013).

Figure 2: Self-Citations Rates of Major Dedicated TIM Journals (1999 - 2013)

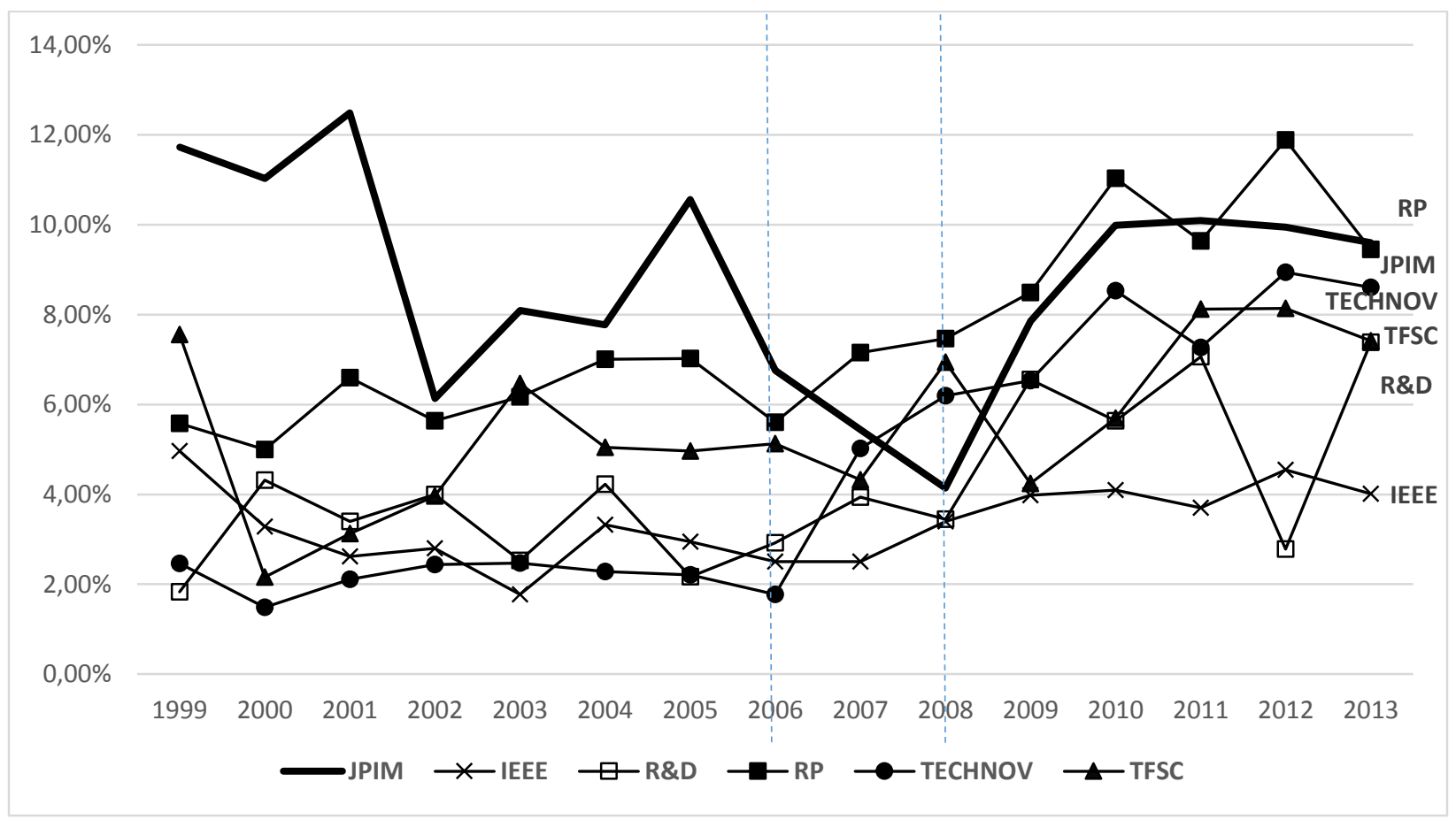

One possible explanation to this increase in self-citation is that over time, the body of knowledge in the major TIM journals has grown and matured; and these journals have published enough content to become a source of knowledge for their own articles. However, if we consider the evolution of the journals' impact factor as shown in Figure 1, a complementary explanation may be considered. It is possible that the emphasis on increasing impact factors (starting 20052007) has driven the increase in self-citation started in 2006/2008. As the journals in this domain area have gained in reputation, authors have felt more compelled to cite them. 
$\underline{\text { Self-Citation vs. Cross-Citation of Major TIM Journals (1999 - 2013) }}$

In order to complement our understanding of the journals' citation dynamics for each of the six major TIM journals, we analyzed a comparison of the evolution of their rates of self-citation and of cross-citation with the other five journals. Plots of these rates are presented in Figure 3.

Figure 3a shows that after peaking in 2004-2006, cross-citation rates of other major TIM journals in JPIM have steadily decreased over the years. JPIM went from being a major 'crossciter' (12\%-13\% of total citations) to only about $3 \%$ of its citations coming from the five other major TIM journals by 2013.

On the other hand, R\&D Management, Research Policy, and Technovation show the highest propensity to cite the knowledge created in major TIM journals in recent years (Figures 3c, 3d, and 3f). While historically low, since 2007 Technovation has shown an increasing tendency to cite the other TIM journals. Over the years, TFSC and IEEE Transactions on Engineering Management show the lowest propensity to cite knowledge from the other major TIM journals ( $1 \%-3 \%$ of their references; Figures $3 \mathrm{~b}$ and $3 \mathrm{e})$. This tendency has remained fairly consistent. Interestingly, IEEE Transactions on Engineering Management also displays the lowest rates of self-citation in the set. Among the journals considered, JPIM, TFSC, and IEEE Transactions on Engineering Management tend to be most isolated in terms of knowledge imported from the other major TIM journals.

Overall TFSC and JPIM display some of the highest differentials between self-citation and cross-citations from the other major TIM journals. While R\&D Management, Research Policy, Technovation, and IEEE Transactions on Engineering Management show the lowest gap between self-citation rates and citation rates of other major TIM journals. 
Figure 3: Self-Citation vs. Cross-Citation Rates of Other Major TIM Journals (1999 - 2013)

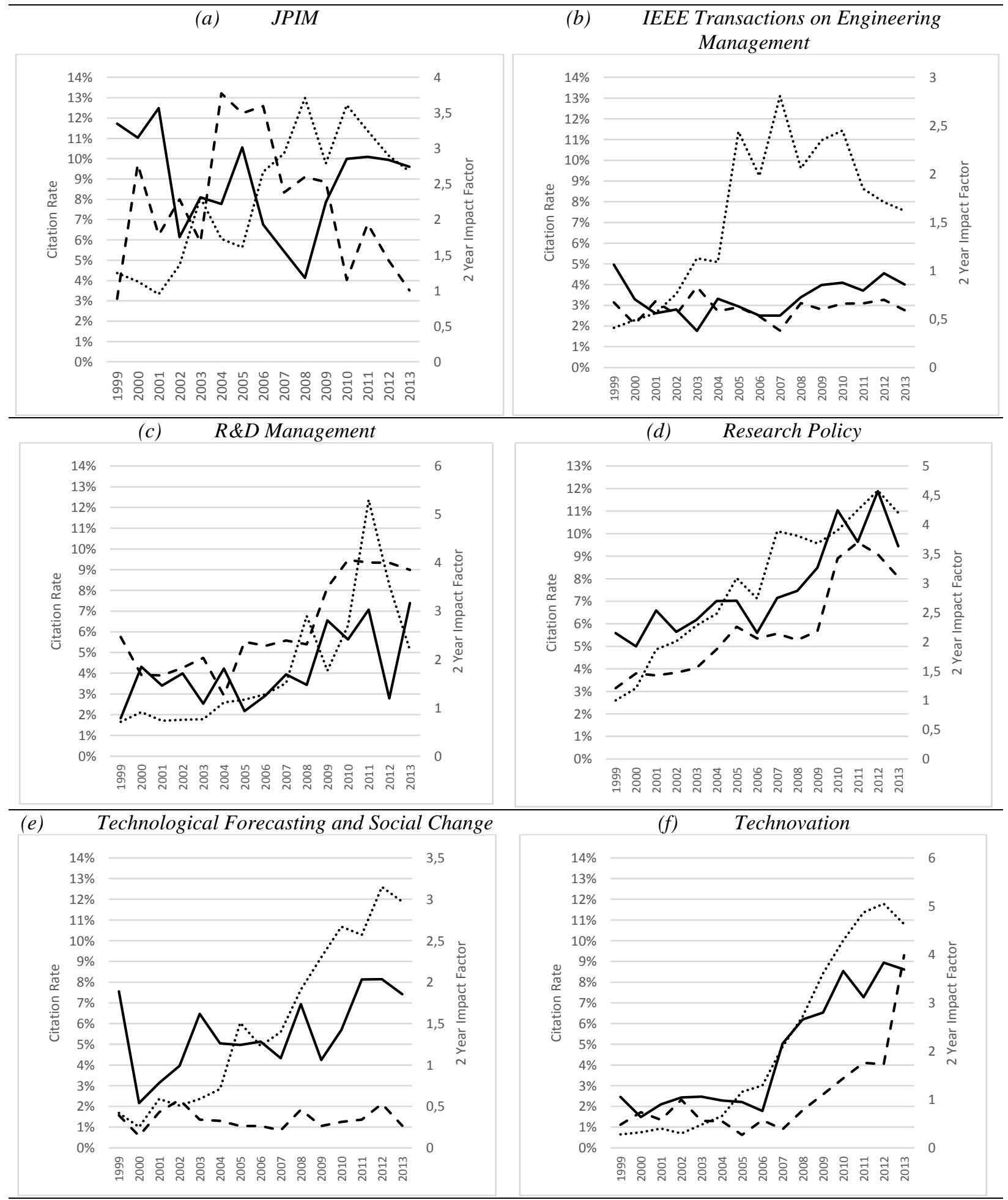

Self-citation rate

- --.-Citation rate of other TIM journals .......... Journal impact factor 


\section{$\underline{\text { Self-Citation Rates, Cross-Citation Rates, and Impact Factor }}$}

Next, we investigated the relationship between self-citation, cross-citation of other TIM journals, and the 2-year impact factor of the journals in our consideration set. Table 1 shows the descriptive statistics and the correlation matrix of our data. Self-citation and cross-citation of other TIM journals were significantly and positively correlated with the 2-year impact factor (.62 and .39 respectively).

Table 1: Descriptive Statistics and Correlation Matrix

\begin{tabular}{|c|c|c|c|c|c|c|c|}
\hline & Mean & S.D. & Min & Max & \multicolumn{3}{|c|}{ Correlations } \\
\hline & & & & & 1 & 2 & 3 \\
\hline 1 IF & 1.26 & 0.8 & 0.21 & 3.28 & 1.00 & & \\
\hline 2 Self-citation & 5.66 & 2.78 & 1.48 & 12.48 & $0.62^{* * * *}$ & 1.00 & \\
\hline 3 Cross-citation & 4.41 & 3.06 & 0.57 & 13.2 & $0.39^{* * * *}$ & $0.47^{* * *}$ & 1.00 \\
\hline
\end{tabular}

We further examined the effect of self-citation and cross-citation of other major TIM journals on the 2-year impact factor, by estimating three regression models. In Model 1, we regressed the 2-year impact factors on the self- and cross-citation rates of all six major TIM journals. In Model 2, we ran the same regression on five major TIM journals excluding JPIM. Models 1 and 2 provide a good baseline for examining the effect of self- and cross-citation on the two-year impact factor knowing that we used fixed effects to control for the heterogeneity among journals. In Model 3, we focused exclusively on JPIM only. This way, we can compare the effects estimated for JPIM (Model 3) with those obtained for the five other journals (Model 2). The standardized regression results are presented in Table 2.

The estimation of Model 1 shows that as expected, both self-citation and cross-citation of TIM journals have a significant and positive effect on the 2-year impact factor of all major TIM journals at an aggregate level $(\beta=.56, \mathrm{p}<.01 ; \beta=.11, \mathrm{p}<.01$ respectively). In addition, selfcitation rates have five times as strong an effect on impact factor compared to citation of other 
major TIM journals. These effects still hold once JPIM is taken out of the sample of the TIM journals (Table 2, Model 2). The effect of self-citation on impact factor becomes even stronger as compared to the overall sample; the effect of self-citation on impact factor is still over five times greater than the effect of cross-citation of other TIM journals $(\beta=.73, p<.01$ vs. $\beta=.13$, $\mathrm{p}<.05)$. These results seem to indicate that self-citation, and citation of the major journals in the TIM domain directly enhances a journal's impact and reputation in general.

Table 2: Effect of Self-Citation and Cross-Citation of Major TIM Journals on 2-Year Impact Factor (Standardized Regression Coefficients)

\begin{tabular}{lccc}
\hline & All TIM journals & $\begin{array}{c}\text { All TIM journals } \\
\text { excluding JPIM }\end{array}$ & JPIM \\
\hline Self-citation & $0.56^{* * *}$ & $0.73^{* * *}$ & $-0.72^{* * *}$ \\
Cross-citation & $0.11^{* * *}$ & $0.13^{* *}$ & $-0.47^{* *}$ \\
\hline Observations & 90 & 75 & 15 \\
VIF & 1.29 & 1.28 & 1.18 \\
$R^{2}$ & 0.395 & 0.626 & 0.468 \\
Adjusted $R^{2}$ & 0.343 & 0.593 & 0.379 \\
\hline
\end{tabular}
One-tailed significance tests. ${ }^{*} p<0.10,{ }^{* *} p<0.05,{ }^{* * *} p<0.01$

However, when these relationships are examined for JPIM alone (Table 2, Model 3), we find that much to our surprise, JPIM bucks the trends displayed by the other journals in the TIM domain. Over the 1999-2013 period, both self-citation and cross-citation of other major TIM journals have a significant and negative effect on the impact factor of $\operatorname{JPIM}(\beta=-.72, \mathrm{p}<.01 ; \beta$ $=-.47, \mathrm{p}<.05)$ with the self-citations having a stronger negative effect than the cross-citations. While seemingly counterintuitive, these results can perhaps be explained by the unique positioning of each journal within the larger TIM domain. Table 3 presents a summary of the self-described positioning of each journal from their own websites. 
Table 3: Positioning of Major Dedicated TIM Journals

\begin{tabular}{|c|c|}
\hline Journal & Positioning (Source) \\
\hline $\begin{array}{l}\text { Journal of } \\
\text { Product } \\
\text { Innovation } \\
\text { Management }\end{array}$ & $\begin{array}{l}\text { An interdisciplinary, international journal that seeks to advance theoretical and } \\
\text { managerial knowledge of new product/service development, and innovation } \\
\text { management in an organization's external and internal environments. Publishes articles } \\
\text { on organizations of all sizes (start-ups, small-medium enterprises, large), from the } \\
\text { consumer, business-to-business, and institutional domains. } \\
\text { (http://onlinelibrary.wiley.com/journal/10.1111/(ISSN)1540-5885/homepage/ProductInformation.html) }\end{array}$ \\
\hline $\begin{array}{l}\text { IEEE } \\
\text { Transactions on } \\
\text { Engineering } \\
\text { Management }\end{array}$ & $\begin{array}{l}\text { Publishes articles on management of technical functions such as research, } \\
\text { development, and engineering in industry, government, university, and other settings. } \\
\text { Emphasis is on studies carried on within an organization to help in decision-making or } \\
\text { policy formation for research, development and engineering. } \\
\text { (http://ieeexplore.ieee.org/xpl/aboutJournal.jsp?punumber=17\#AimsScope) }\end{array}$ \\
\hline $\begin{array}{c}R \& D \\
\text { Management }\end{array}$ & $\begin{array}{l}\text { Publishes articles of interest to practicing managers and academic researchers in } \\
\text { R\&D and innovation management. Covering the full range of topics in research, } \\
\text { development, design and innovation, and related strategic and human resource issues - } \\
\text { from exploratory science to commercial exploitation - and examining social, economic } \\
\text { and environmental implications. } \\
\text { (http://onlinelibrary.wiley.com/journal/10.1111/(ISSN)1467-9310/homepage/ProductInformation.html) }\end{array}$ \\
\hline Research Policy & $\begin{array}{l}\text { A multi-disciplinary journal devoted to analyzing, understanding and responding to } \\
\text { the economic, policy, management, organizational, environmental and other } \\
\text { challenges posed by innovation, technology, } R \& D \text { and science on the one hand, and } \\
\text { economic, social, political and organizational processes, on the other. This includes a } \\
\text { number of related activities concerned with the creation, diffusion, acquisition and } \\
\text { exploitation of knowledge (in the form of new or improved products, processes or } \\
\text { services). Findings must have implications for policy or management. } \\
\text { (https://www.journals.elsevier.com/research-policy/) }\end{array}$ \\
\hline $\begin{array}{c}\text { Technological } \\
\text { Forecasting and } \\
\text { Social Change }\end{array}$ & $\begin{array}{l}\text { The journal offers a forum for those wishing to deal with the methodology and practice } \\
\text { of technological forecasting and future studies as planning tools as they } \\
\text { interrelate social, environmental and technological factors. } \\
\text { (https://www.journals.elsevier.com/technological-forecasting-and-social-change/) }\end{array}$ \\
\hline Technovation & $\begin{array}{l}\text { An interdisciplinary journal that encompasses all facets of technological innovation. } \\
\text { Technological innovation is considered from both process and product perspectives, } \\
\text { social innovations, and conceptualization to commercialization of a new technology- } \\
\text { based products or processes in all forms of enterprise, political and economic systems. } \\
\text { (https://www.journals.elsevier.com/technovation/) }\end{array}$ \\
\hline
\end{tabular}

From Table 3 it can be seen that JPIM (along with Research Policy, Technovation, and

$R \& D$ Management), has the broadest positioning statements of the journals under consideration.

Over the years, while the other journals seemed to have anchored more strongly in the TIM

literature (as indicated by their relatively higher rates of self- and cross-citations), JPIM seems to 
have broadened its appeal and knowledge base beyond the traditional TIM domain. In recent years, JPIM seems to be placing greater emphasis on theoretical grounding in core business disciplines (i.e., management, strategy, marketing, IS, operations) beyond the traditional TIM literature (including self-citations). This would result in an increase knowledge import from (and hopefully export to) the core businesses disciplines - as indicated by an increasing impact factor of JPIM, despite a significant negative relationship with both self-citation and cross-citation rates of other major TIM journals. It would be interesting to see the knowledge flows between JPIM and the major journals in the core business disciplines over this period to shed more light on this rather unusual finding.

\section{Conclusions}

The purpose of this essay was to examine the knowledge exchange patterns between the major TIM journals. In so doing, we examine 4,171 articles and 29,776 citations from the top six dedicated TIM journals from 1999 - 2013. The bibliometric analysis presented here gives us one of the most comprehensive and detailed year-by-year look at the intra-domain knowledge exchange over a 15-year period. Our analyses indicate that:

- All the major dedicated TIM journals included in the analysis showed significant increases in their impact factors beginning 2005-2007.

- The increase in the impact factors of the journals coincides with increasing selfcitation by all the major TIM journals, starting 2006-2008. Research Policy, Technovation, JPIM, and TFSC exhibit the highest self-citation rates among the major dedicated TIM journals. This could be a sign of development and maturity of the TIM as a field of study - with domain-specific knowledge reaching critical mass and generating self-referencing. 
- After exhibiting the highest self-citation rates in the set from 1999-2005, JPIM selfcitation rates became more consistent with those of other major TIM journals starting 2007-2008.

- From 1999-2013 R\&D Management, Research Policy, and lately Technovation have shown an increasing tendency to cite other major TIM journals in the consideration set, suggesting that they may be becoming more deeply rooted in the TIM literature.

- JPIM, TFSC, and IEEE Transactions on Engineering Management on the other hand, tend to cite the other major TIM journals the least. The tendencies displayed by IEEE Transactions on Engineering Management and TFSC might be explained by their very specific and specialized positioning within the TIM domain, which reduces overlap with other major TIM journals (see Table 3). The knowledge exchange patterns displayed by JPIM might be indicative of a broadening of JPIM's appeal, and knowledge base beyond the traditional TIM domain.

Overall, our findings suggest that the major TIM journals seem to be bifurcating in how they exchange knowledge within the domain. Half of the journals considered (i.e., $R \& D$ Management, Research Policy, Technovation) seem to be becoming more firmly rooted in the domain, while the other half (i.e., JPIM, TFSC, IEEE Transactions on Engineering Management) seem to be becoming more insulated from the other TIM journals, for various reasons. 


\section{References}

Biggadike, Ralph E. (1981), “The Contributions of Marketing to Strategic Management," Academy of Management Review, 6 (4), 621-631.

Clark, Terry, Thomas Martin Key, Monica Hodis, and Daniel Rajaratnam (2014), "The Intellectual Ecology of Mainstream Marketing Research: An Inquiry into the Place of Marketing in the Family of Business Disciplines," Journal of the Academy Marketing Science, 42, 223-241.

Day, George S. (1992), “Marketing's Contribution to the Strategy Dialog,” Journal of the Academy of Marketing Science, 20 (4), 323-329.

Day, George. S., and David B. Montgomery (1999), "Charting New Directions for Marketing," Journal of Marketing, 63 (4), 3-13.

Di Benedetto, Anthony, Shikhar Sarin, Mustapha Belkhouja and Christophe Haon (Forthcoming 2018), "Patterns of Knowledge Outflow from Industrial Marketing Management to Major Marketing and Specialized Journals (1999-2013): A Citation Analysis,” Industrial Marketing Management.

Linton, Jonathan and Narongsak (Tek) Thongpapanl (2004), "Ranking the Technology Innovation Management Journals," Journal of Product Innovation Management, 21, 123139.

Pieters, Rik and Hans Baumgartner (2002), "Who Talks to Whom? Intra- and Interdisciplinary Communication of Economics Journals," Journal of Economic Literature, 40 (June), 483509.

Reibstein, David. J., George S. Day, and Yoram Wind (2009), "Is Academic Marketing Losing Its Way?” Journal of Marketing, 73 (4), 1-3. 
Shafiq, Muhammad (2013), "Thinking Inside the Box? Intellectual Structure of the Knowledge Base of Innovation Research (1988-2008),” Strategic Management Journal, 34, 62-93. Varadarajan, P. Rajan., and Satish Jayachandran, (1999), "Marketing Strategy: An Assessment of the State of the Field and Outlook," Journal of the Academy of Marketing Science, 27 (2), 120-143. 